PRZEGLĄD BIBLIOTECZNY 2017 z. 2

PL ISSN 0033-202X

\title{
ZWIĄZEK BIBLIOTEKARZY POLSKICH W IFLA. POCZĄTKI WSPÓŁPRACY
}

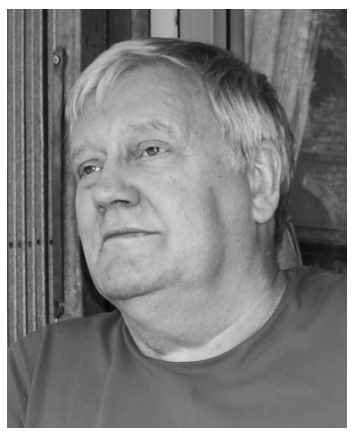

Andrzej Mężyński, dr hab. nauk historycznych, w latach 19612003 pracował w bibliotekach naukowych, m.in. w Bibliotece Kórnickiej PAN (1961-1980), w Bibliotece Uniwersyteckiej w Warszawie, później dyrektor Biblioteki Sejmowej. W latach 2003-2009 profesor w Instytucie Informacji Naukowej i Bibliotekoznawstwa w Uniwersytecie Wrocławskim. Współzałożyciel (1988) i wiceprezes Polskiego Towarzystwa Bibliologicznego. Autor dziewięciu książek dotyczących bibliotekoznawstwa, historii książki polskiej w XIX i XX w., historii polskich bibliotek w czasie II wojny światowej, ostatnia z nich, to Biblioteki Warszawy w latach 19391945 (Warszawa 2010).

SŁOWA KLUCZOWE: Związek Bibliotekarzy Polskich 1928-1939. IFLA 1928-1939.

ABSTRAKT: Teza/cel artykułu - artykuł przypomina okoliczności historyczne, w których Związek Bibliotekarzy Polskich wstępował w 1928 r. do IFLA. Opisany jest udział polskich bibliotekarzy w pracach tej organizacji, przede wszystkim w jej dorocznych sesjach, a również w dwóch podkomisjach IFLA. Metody - podstawowym źródłem było wydawnictwo IFLA: Actes du Comité international des bibliothèques, wykorzystano również polskie publikacje źródłowe i dokumentacyjne. Wyniki/wnioski - Polska wcześnie wstąpiła do IFLA zyskując przez to możliwość śledzenia najnowszych tendencji w bibliotekarstwie światowym, a niektóre z nich wprowadzając w życie. Wkład merytoryczny w prace IFLA nie był znaczący - polskie bibliotekarstwo organizowało się wtedy po okresie zaborów i nie zdołało wyłonić jeszcze ośrodków myśli bibliotekarskiej. 
W październiku 2017 r. bibliotekarstwo polskie będzie obchodzić stulecie swojej organizacji zawodowej - powstałej jako Związek Bibliotekarzy Polskich $(Z B P)^{1}$. W lecie tegoż roku w dniach 19-25 sierpnia odbędzie się we Wrocławiu 83. Konferencja Generalna Międzynarodowej Federacji Stowarzyszeń Bibliotekarskich (IFLA), trzecia już tej rangi impreza IFLA w Polsce ${ }^{2}$. Z tej okazji warto przypomnieć okoliczności, w jakich Związek Bibliotekarzy Polskich nawiązał w latach 20. XX w. współpracę z tą organizacją i opisać wzajemne kontakty w tym czasie. Obie organizacje były wtedy stosunkowo młode. ZBP założono później niż podobne stowarzyszenia w Europie Zachodniej i w Stanach Zjednoczonych. Pierwsze stowarzyszenie bibliotekarzy na świecie: American Library Association (ALA) powstało w Stanach Zjednoczonych w 1876 r., rok później zrzeszyli się bibliotekarze brytyjscy (Library Association, LA). W ślad za nimi zorganizowali się bibliotekarze Austrii (1890), Niemiec (1900), Francji (1906). We wszystkich tych krajach bibliotekarze pracujący w dużych, zasobnych bibliotekach, znaleźli się w sytuacji, w której konieczność współpracy między bibliotekami stawała się niezbędna, choćby dla wspólnego zapanowania nad informacją w rosnącym lawinowo (już wtedy!) piśmiennictwie naukowym.

W Polsce, podzielonej na trzy zabory, sytuacja była odmienna. Duże biblioteki naukowe, które wszędzie były inicjatorami pomysłów integracyjnych, właściwie nie istniały. Jedynie w Galicji funkcjonowały dwa polskie uniwersytety, względnie autonomiczne i ich biblioteki: Jagiellońska i Uniwersytetu Lwowskiego. We wszystkich trzech zaborach rozwinięte były natomiast sieci bibliotek oświatowych, zakładane przez działaczy społeczników, którzy nieśli „,kaganek oświaty” w lud, dbając jednocześnie o jego edukację narodową. Nasze stowarzyszenie bibliotekarskie powstało w zaborze rosyjskim, gdzie nie było żadnej polskiej biblioteki uniwersyteckiej, rozwinięty był za to najsilniej ruch bibliotekarstwa oświatowego. Działaczy oświatowych wspierała inteligencja warszawska: historycy, prężnie działające środowisko bibliofilskie i inni ludzie książki.

Początkowo Związek nie rozwijał szerszej działalności, przeszkodą były burzliwe wydarzenia polityczne - w czasie wojny z bolszewikami w $1920 \mathrm{r}$. działania ZBP ustały. Ożywiły się ponownie po 1926 r., kiedy na czele Związku stanął Edward Kuntze, dyrektor Biblioteki Jagiellońskiej, zwolennik związania polskiego bibliotekarstwa z bibliotekarstwem światowym. Nie było to proste, gdyż bibliotekarstwo światowe samo szukało po I wojnie światowej najdogodniejszych form współpracy. Początkowo inicjatywy integracyjne wychodziły z kół bibliofilskich. W 1923 r. odbył się w Pary-

\footnotetext{
${ }^{1}$ Zebranie inauguracyjne Związku Bibliotekarzy Polskich odbyło się w Warszawie 21 X 1917 r. Najnowsza monografia Związku pod red. Jadwigi Koniecznej ukaże się w 2017 r.

${ }^{2}$ Po raz pierwszy Sesja IFLA (IX) odbyła się w dniach 31 V - 2 VI 1936 r. w Warszawie. Po raz drugi, również w Warszawie, IFLA obradowała w dniach 14-17 IX 1959 r. (Sesja XXV).
} 
żu Międzynarodowy Kongres Bibliotekarzy i Bibliofilów, który dał początek następnym tego typu spotkaniom w międzywojennej Europie: Praga 1926 r., Rzym 1929 r., Madryt/Barcelona 1935 r. ${ }^{3}$. We wszystkich tych Kongresach wzięli udział polscy bibliotekarze i bibliofile, występując z referatami $^{4}$ (Więckowska, 1973, s. 197-226) .

Dla bibliotekarzy szczególnie istotny był kongres praski - „Międzynarodowy Kongres Bibliotekarzy i Przyjaciół Książki w Pradze”. Wzięło w nim udział 78 przedstawicieli z Polski, którzy wygłosili 18 referatów. Podczas Kongresu w jednej sekcji podniesiono i dyskutowano zagadnienia międzynarodowej współpracy bibliotek i potrzebę powołania organizacji zrzeszającej bibliotekarzy. Bibliotekarz francuski Gabriel Henriot, przewodniczący francuskiej organizacji bibliotekarzy (Association des bibliothécaires français), upoważniony przez Kongres praski, przedstawił projekt powołania międzynarodowej organizacji bibliotekarskiej na konferencji Stowarzyszenia Bibliotek Amerykańskich, zorganizowanej w październiku 1926 r. z okazji 50-lecia powstania ALA. Amerykanie poparli myśl europejską i wystosowali, do czynnych już na świecie stowarzyszeń bibliotekarskich, ankietę z pytaniami o zakres zadań przyszłej organizacji i o deklarację, czy dane stowarzyszenie zgłosi chęć przystąpienia do niej5.

Na ankietę odpowiedziało pozytywnie 9 krajów, w tym Polska. Podpis pod tą odpowiedzią złożył prawdopodobnie Edward Kuntze, od 1926 r. przewodniczący Związku Bibliotekarzy Polskich. Wyniki ankiety zostały zaprezentowane rok później (1927) w Edynburgu na konferencji zwołanej z okazji 50-lecia brytyjskiego Stowarzyszenia Bibliotek. Na tej konferencji powołano (30 września) Międzynarodowy Komitet Bibliotek i Bibliografii (International Library and Bibliographical Committee). Deklarację przystąpienia do Komitetu podpisało 15 państw, delegacji Polski w Edynburgu jednak nie było. Pierwsza sesja Komitetu odbyła się w Rzymie w marcu $1928 \mathrm{r}$.

Zgromadzenie Delegatów Kół ZBP podpisało 28 kwietnia 1928 r. „, rezolucję edynburską", przystępując do Komitetu ${ }^{6}$. Zdecydowano w IFLA, że każde stowarzyszenie może delegować jedną osobę z prawem głosu, co nie wykluczało możliwości brania udziału w posiedzeniach dowolnej liczby bibliotekarzy z danego kraju. ZBP wybrał jako swojego delegata Jana Muszkowskiego.

\footnotetext{
${ }^{3}$ Spotkanie rzymskie (1929) i madrycko-barcelońskie (1935) nosiły nazwę „,Kongresy bibliotek i bibliografii". Spotkania te (również paryskie - 1923 r. i praskie - 1926 r.), często dużej skali i imponującej frekwencji, są czasami w literaturze opisywane jako sesje IFLA, tymczasem pierwsze dwa odbyły się jeszcze przed zawiązaniem tej organizacji, a ich animatorami byli początkowo nie tylko bibliotekarze, lecz ludzie książki w ogóle, przede wszystkim bibliofile, bibliografowie, pisarze, księgarze i wydawcy.

${ }^{4}$ Udział polskich bibliotekarzy w międzynarodowym ruchu bibliotekarskim najpełniej omówiła Helena Więckowska (1973).

${ }^{5}$ Ankietę wysłał prezes ALA William Bishop.

${ }^{6} \mathrm{ZBP}$ wnosił odtąd roczną składkę w wysokości 60 groszy od członka Związku, w zamian otrzymywał w 5 egzemplarzach wszystkie wydawnictwa IFLA.
} 


\section{Féde'sation Liturnationale der associations de lithothéavies.}

\section{INTERNATIONAL FEDERATION OF LIBRARY ASSOCIATIONS}

\section{STA TUTES.}

Sec. 1. The name of this organisation shall be the International Federation of Library Associations.

Sec. 2. The object of the Federation shall be to promote international library cooperation.

Sec. 3. Members of the Federation shall be those Library Associations of national (or wider) scope which approve these resolutions and which comply with such other provisions as are adopted from time to time.

Sec. 4. The affairs of the Federation shall be administred by the International Library Committee; this committee shall consist of representatives selected by associations which are members of the Federation. There shall be from each country only one designated member or substitute with the right to vote. But with him may be associated delegates. Delegates are elected for a period not exceeding 5 years but are ligible for reelection

Sec. 5. The duties of the Committee shall be to select the time and place for international library conferences and with the cooperation of local committees to prepare programs for such conferences; and to make investigations and recommendations concerning international relations between libraries, organizations of librarians and bibliographers and other agencies.

Sec 6. International library conferences shall be held at least once in five years. Plenary sessions of the Committee must be held in connection with each international library conference. Other sessions may be held at the call of the Chairman and must be held when requested by one third of the Committee.

Sec. 7. The Committee shall have power to appoint sub-committees from its own membership or from the membership of any of the cooperating library associations.

Sec. 8. The officers of the Federation and of the Committee shall be a President, two Vice Presidents and a Secretary. These officers shall constitute, the executive beard and shall be elected by the committee for a term to expire not later than twelve" months after the close of each congress. The Secretary may be, but need not be, a member of the Committee designated by some national association. He shall have the right to yote.

Vacancies on the Executive Committee shall: be filled by the Committee,"

Sec. 9. Annual dues for each member Association shall be fixed at a rate between 25 and fifty centimes (Swiss) for each member of that association or on a basis of 5 or $10 \%$ of the receipts from membership dues of the associatons, but shall not be more than 2.500 francs (Swiss) for any association. Dues shall be payable to the Secretary on or before March 1 for each calendar year.

The amount of the dues will form the budget of the Association.

Sec. 10. Any association may withdraw from the Federation if its dues for that year have been paid.

Sec. 11. By-laws may be adopted by the Committee.

Sec. 12. Resolutions adopted by the Committee or by any Congress held under its auspices shall not be binding on any member association until ratified by that association.

$$
\begin{aligned}
& \text { June } 1929 . \\
& \text { Venice 2y }
\end{aligned}
$$

Zdj. 1. Pierwszy statut IFLA przyjęty w Wenecji 29 czerwca $1929 \mathrm{r}$.

[źródło: http://www.ifla.org/files/assets/hq/history/1929_statutes.pdf]. 
Wziął on po raz pierwszy udział w pracach w 2. Sesji Komitetu, która odbyła się w ramach Światowego Kongresu Bibliotek i Bibliografii we Włoszech w dniach 15-30 czerwca 1929 r. Podczas tej sesji zmieniono nazwę Komitetu na „Międzynarodową Federację Stowarzyszeń Bibliotekarskich” (IFLA), a Muszkowski zgłosił wniosek o powołanie Podkomisji Statystyki Produkcji Wydawniczej, którą utworzono, a wnioskodawca stanął na jej czele. Powierzenie stanowiska przewodniczącego podkomisji było wówczas wyróżnieniem dla polskiego bibliotekarstwa, nieznanego przecież na forum międzynarodowym, o wyborze tym zdecydował najwyraźniej osobisty autorytet Muszkowskiego, wrażenie robił choćby i ten fakt, iż był on poliglotą.

IFLA obradowała corocznie: Sztokholm (1930), Cheltenham (Anglia, 1931), Berno (1932), Chicago i Avignon (1933), Madryt (1934), Madryt i Barcelona (1935), Warszawa (1936), Paryż (1937), Bruksela (1938), Haga i Amsterdam (1939). Polskę na sesjach IFLA do 1936 r. reprezentował Muszkowski . Składał on sprawozdania z działalności polskich bibliotek w latach 1930-1932, publikowane w wydawnictwie IFLA „Actes du Comité international des bibliothèques". W Chicago (1933) wygłosił odczyt o polskich bibliotekach, przedstawiając ich stan współczesny, osiągnięcia, ale i problemy. Podczas tej Sesji, podzielonej między Chicago i Avignon, Muszkowski był nadzwyczaj aktywny. Na drugim posiedzeniu Sesji w Avignonie wygłosił referat o wypożyczaniu międzybibliotecznym w Polsce, a dodatkowo w „Actes..." opublikował wyniki prac podkomisji pracującej nad porządkowaniem zasad międzynarodowej statystyki druków. W tym czasie doprowadził w kraju do utworzenia, w ramach Związku Bibliotekarzy Polskich, Sekcji ds. Międzynarodowych i stanął na jej czele.

Muszkowskiemu zawdzięcza też Polska wybór Warszawy na miasto organizujące w dniach 31 maja - 2 czerwca 1936 r. 9. Sesję IFLA. Zgłosił on polską kandydaturę na sesji w Madrycie 20-30 maja 1935 r., gdzie po dyskusji propozycję tę przyjęto. Warszawskie obrady IFLA były sukcesem organizacyjnym. Nie wszyscy polscy bibliotekarze byli zresztą zadowoleni z faktu przeprowadzenia tych obrad w Polsce. Polskie bibliotekarstwo jest w stanie organizacji - argumentowali przeciwnicy - i nie stać nas jeszcze na wydawanie pieniędzy na szumne imprezy międzynarodowe, które nie przyniosą nam żadnej namacalnej korzyści. Przeważył jednak głos bibliotekarzy, takich jak Kuntze i Muszkowski, zdających sobie sprawę, że odizolowanie polskiego bibliotekarstwa od świata byłoby strategicznym błędem i sesja się odbyła. Przyjechało 34 delegatów z 17 krajów z 3 kontynentów. Delegatów przyjął na Zamku Królewskim prezydent Ignacy Mościcki, a w ratuszu prezydent miasta Stefan Starzyński. Obrady IFLA połączono, z inicjatywy Muszkowskiego, z IV Zjazdem Biblioteka-

${ }^{7}$ Z wyjątkiem 1934 r., gdy do Madrytu nie pojechał. 


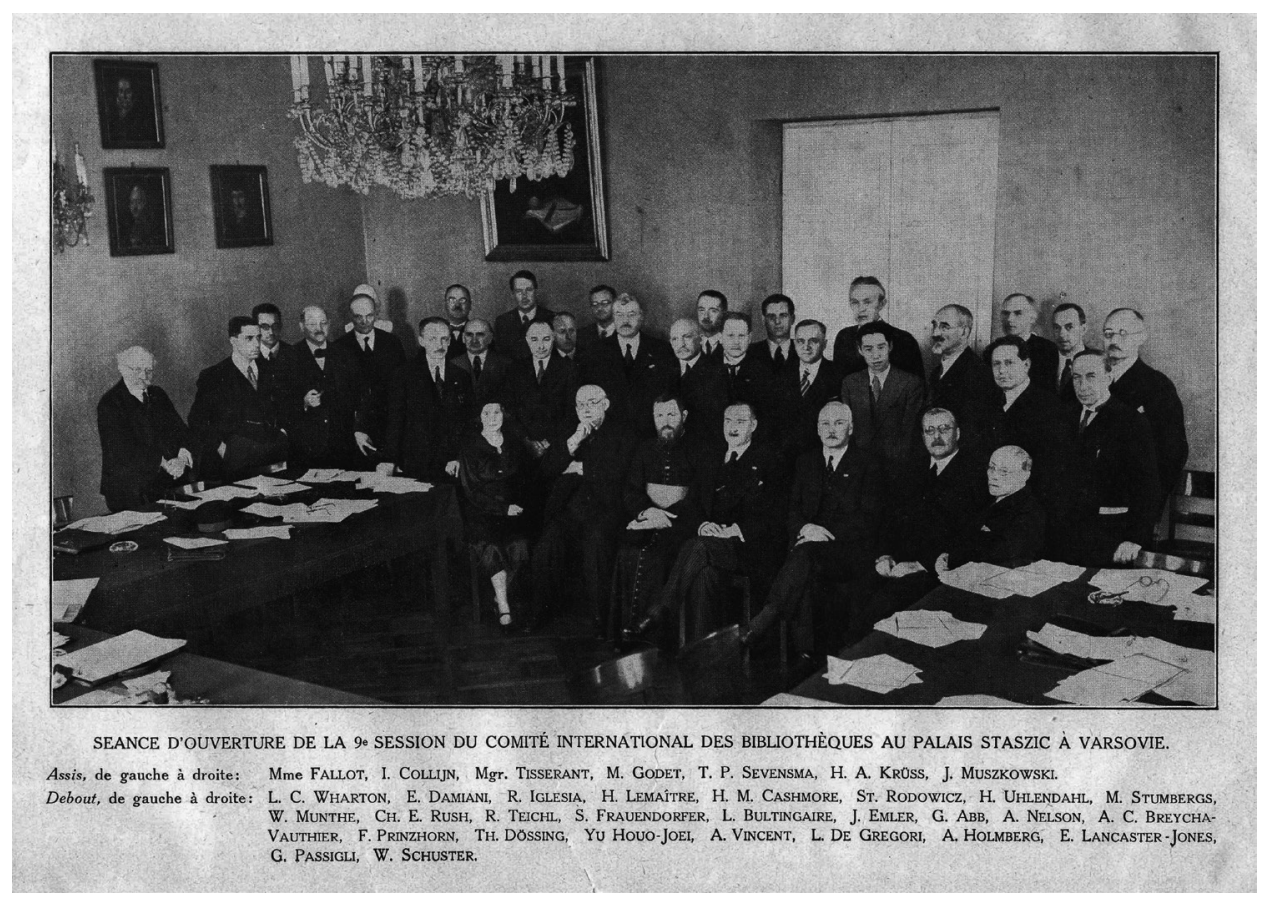

Zdj. 2. Członkowie posiedzenia inauguracyjnego IX Sesji IFLA w Pałacu Staszica w Warszawie, 31 maja 1936 r. [źródło: Actes du Comité international des bibliothèques: 9me Session. Varsovie, 31 Mai - 2 Juin 1936, Fédération intern. des assoc. de bibliothécaires].

rzy Polskich, a sam Muszkowski przewodniczył Komitetowi Organizacyjnemu obydwóch Zjazdów. Pomysł Muszkowskiego był celny i z tego powodu, że członkowie Komitetu IFLA mogli się naocznie przekonać o stanie i organizacji polskiego bibliotekarstwa. IV Zjazd był wyjątkowo licznie obsadzony, wzięło w nim udział 519 uczestników, a referaty zjazdowe wydrukowano jeszcze przed Zjazdem w opasłym tomie (IV Zjazd Bibliotekarzy Polskich w Warszawie, Referaty, 1936), co na ogół rzadko udaje się organizatorom, i co z pewnością zagraniczni goście dostrzegli. Po zakończeniu obrad ich uczestnicy wyjechali do Krakowa, Wieliczki i Zakopanego. W Krakowie obejrzeli nowo wybudowany gmach Biblioteki Jagiellońskiej, który wywarł na nich duże wrażenie. Fakt, iż obrady jednej z sesji IFLA odbyły się w Polsce, nie wzbudzał jednak w kraju zbytniego zainteresowania. Głosy w prasie były nieliczne, milczały nawet periodyki bibliotekarskie. Natomiast spotkanie to obszernie zrelacjonowano, $\mathrm{w}$ formie sprawozdania, $\mathrm{w}$ jednym $\mathrm{z}$ dwóch woluminów poświęconych IV Zjazdowi Bibliotekarzy (IV Zjazd Bibliotekarzy Polskich w Warszawie. Protokoty, 1936).

Warszawska sesja IFLA była ostatnia, w której wziął udział Muszkowski. Ordynat Edward Krasiński zwolnił go z funkcji dyrektora Bibliote- 
ki Ordynacji Krasińskich, co spowodowało, że Muszkowski, załamany, zaczął wycofywać się z bibliotekarstwa, zrzekając się również funkcji w IFLA ${ }^{8}$. Prezydent IFLA Marcel Godet przyjął rezygnację Muszkowskiego z żalem, czemu dał wyraz podczas 10. Sesji, która odbyła się w Paryżu w sierpniu 1937 r. Przyczyną rezygnacji Muszkowskiego mogły być też nikłe rezultaty jego starań jako kierownika podkomisji statystyki wydawniczej. Nie udawało się uzgodnić przez długie lata nawet najprostszych zasad tej statystyki, a niepowodzenie spotkało zresztą także następcę Muszkowskiego na tym stanowisku, niemieckiego bibliotekarza Heinricha Uhlendala.

W miejsce Muszkowskiego ZBP delegował do Komitetu IFLA Józefa Grycza. W latach 1930-1939 pracował on w Departamencie Nauki Ministerstwa Wyznań Religijnych i Oświecenia Publicznego, który sprawował zwierzchność nad publicznymi naukowymi bibliotekami państwowymi w Polsce. Grycz wziął udział w 10. Sesji IFLA w Paryżu w 1937 r. Wygłosił na niej referat o stanie bibliotek polskich (Grycz, 1937, s. 163-165). W następnej, 11. sesji IFLA w Brukseli jako delegat ZBP wziął udział Aleksander Birkenmajer, wówczas kierownik Działu Rękopisów Biblioteki Jagiellońskiej. Na Sesji tej towarzyszył mu Grycz (bez prawa głosu) jako członek Podkomisji Normalizacyjnej w zakresie Książek i Bibliotek (Sub-Committee on Normalization in the Field of Books and Libraries) ${ }^{9}$ (Birkenmajer \& Grycz, 1938, s. 162-164). Grycz był w okresie międzywojennym drugim po Muszkowskim Polakiem, członkiem Podkomisji IFLA. Wybór Grycza do tego zespołu był uzasadniony, gdyż był on w obszarze polskiego bibliotekarstwa, wraz z Adamem Łysakowskim, rzecznikiem ujednolicenia procedur bibliotekarskich, poczynając od ustalenia wspólnych norm katalogowania poszczególnych kategorii zbiorów bibliotecznych. Wspierał również pomysły wprowadzenia wspólnych standardów międzynarodowych, co było jednym z zasadniczych zadań IFLA. Grycz był bibliotekarzem-praktykiem, specjalnie predestynowanym do przenoszenia na grunt polskiego bibliotekarstwa najnowszych regulacji IFLA, które obserwował włączywszy się w prace Federacji. Doprowadził też do powołania (12 listopada 1937 r.) przez ZBP Komisji Normalizacyjnej w zakresie bibliotekoznawstwa, książki i czasopiśmiennictwa. Komisja nie zdążyła jednak rozwinąć przed wojną działalności. IFLA przywiązywała dużą wagę do prawnego uregulowania międzynarodowych wypożyczeń bibliotecznych. Sprawa ta interesowała bardzo polskie biblioteki, których czytelnicy chętnie sięgali po lektury przechowywane w bibliotekach zagranicznych, także rękopisy

\footnotetext{
${ }^{8}$ Muszkowski wycofał się również z Komitetu Rzeczoznawców Bibliotecznych.

${ }^{9}$ Obaj bibliotekarze przygotowali wspólnie sprawozdanie z działalności polskich bibliotek w latach 1937-1938.
} 
i stare druki. Idąc za dyrektywami IFLA polskie Ministerstwo Wyznań Religijnych i Oświecenia Publicznego wydało 11 stycznia 1939 r. opracowane przez Grycza „Zarządzenie o międzynarodowych wypożyczeniach międzybibliotecznych”, do którego dołączono „Regulamin międzynarodowego wypożyczania zbiorów bibliotecznych", będący przekładem regulaminu opracowanego przez IFLA.

Inną inicjatywą IFLA było zwrócenie uwagi na wzrastającą rolę dokumentacji w pracy bibliotek. Polskie biblioteki nie były organizacyjnie przygotowane do wypełniania takich zadan. Józef Grycz próbował jednak zainicjować w Polsce dyskusję o konieczności rozbudowy ośrodków dokumentacji $\mathrm{w}$ polskich bibliotekach, jednak bez widocznych rezultatów. Zaproponował Radzie ZBP, by wystąpiła z inicjatywą powołania Międzynarodowego Centrum Dokumentacji Bibliotekarstwa przy IFLA, wyobrażał sobie, że punkt taki mógłby być usytuowany przy Bibliotece Ligi Narodów w Genewie.

Na ostatnie, przed II wojną światową posiedzenie IFLA (Haga i Amsterdam 1939 r.) Polacy nie pojechali. Wraz z wybuchem II wojny światowej kontakt z IFLA urwał się. W okupowanej Polsce wszystkie stowarzyszenia zostały rozwiązane, również Związek Bibliotekarzy Polskich. Prezes ZBP Adam Łysakowski napisał list do Szwajcara Marcela Godeta, przewodniczącego IFLA. Treść jego nie jest znana. Godet odpowiedział 9 marca 1940 r. deklarując sympatię oraz chęć „zebrania czegoś i przysłania”"10. Na tym kontakty obu organizacji urwały się.

$* * *$

Współpraca polskiego bibliotekarstwa z bibliotekarstwem światowym przebiegała głównie we współdziałaniu z IFLA. Nie były to jednak kontakty jedyne i wyłączne. Bibliotekarze, a także dobrze zorganizowani w Polsce bibliofile, odczuwali spontaniczną potrzebę nawiązywania kontaktów z zachodnim środowiskiem ludzi książki jeszcze przed powstaniem IFLA. Dawali temu wyraz udając się w licznych grupach na kolejne kongresy bibliofilsko-bibliotekarskie, biorąc w nich czynny udział. Przykładem może być wyjazd do Pragi w 1926 r. Inne delegacje polskie, choć mniej liczne, wzięły udział we wszystkich wymienionych wyżej kongresach bibliotekarzy, bibliofilów i bibliografów. Wzorując się na nich, środowiska polskie organizowały swoje Zjazdy. Pierwsze dwa: Kraków 1925 r. i Warszawa 1926 r. odbyły się pod egidą Towarzystwa Miłośników Książki, czyli organizacji bibliofilskiej, choć z dużym wkładem bibliotekarzy, którzy rów-

\footnotetext{
${ }^{10}$ Bibliotekarstwo polskie 1925-1951 w świetle korespondencji jego wspóttwórców. Wybór i oprac. Maria Dembowska, s. 262. O liście tym zawiadomił Łysakowski Mariana Łodyńskiego: Vom Herrn Godet habe ich die Antwort vom 5 März bekommen. Er hat mein Schreiben "Avec la plus vive sympathie” zur Kenntnis genommen und dessen Kopie an die Mitglieder versandt. Er hofft, dass is ihm gelangen wird was zu sammeln und uns zu senden".
} 
nież bywali wybitnymi bibliofilami (np. Kazimierz Piekarski). Następne dwa zjazdy bibliofilów i bibliotekarzy odbyły się już osobno, choć w tym samym miejscu i czasie: Lwów 1928 r., Poznań 1929 r.

Bibliotekarze polscy zaangażowali się też w pracę Komitetu Rzeczoznawców Bibliotecznych (Comité d'experts de bibliothèques) powołanego w ramach Ligi Narodów. Liczył on siedmiu członków, niewątpliwie rekrutujących się z europejskiej elity bibliotekarskiej (wchodzili do niego m.in. przewodniczący IFLA Isak Collijn i Marcel Godet). Członkiem tego wąskiego grona w kadencji 1930-1935 był Jan Muszkowski. Komitet ten podejmował istotne zadania, a niektóre jego uchwały popierała i aprobowała Liga Narodów, jednak możliwości realizacji tych uchwał były ograniczone, choć niektóre wątki przejmowała IFLA do dalszego procedowania i wdrożenia. Niemniej Komitet ten patronował kilku istotnym inicjatywom, jak np. publikacja Index Bibliographicus rejestrująca czasopisma bibliograficzne, bądź takie, które prowadzą stałe działy bibliograficzne z niektórych dziedzin. Dane z Polski do tego wydawnictwa przesyłali bibliotekarze z Biblioteki Jagiellońskiej.

Bez wątpienia zamiar polskich elit bibliotekarskich, by związać się z bibliotekarstwem zachodnioeuropejskim, był zrozumiały, ponieważ konsolidujące się po latach zaborów bibliotekarstwo polskie znajdowało właśnie na Zachodzie wzorce i standardy. Pozostawało jednak pytanie, na ile Polska będzie konsumentem zdobyczy bibliotekarstwa europejskiego, a na ile wniesie do niego swój własny wkład. Było jednak sprawą oczywistą że bibliotekarstwo polskie nie wypracowało wtedy jeszcze żadnych koncepcji teoretycznych ani praktycznych, mogących wspomóc bibliotekarstwo światowe, było na to za wcześnie. $W$ spokojnym tonie napisał o tym Kuntze, wszak jeden z motorów zbliżenia się do Europy: „Nasz stosunek do spraw współpracy międzynarodowej jest raczej bierny - stwierdził on całe współdziałanie opiera się na kilku jednostkach" (Kuntze, 1932, s. 115). Kuntze miał tu na myśli z pewnością Muszkowskiego, a potem Birkenmajera, a być może i siebie samego, gdyż sam też uczestniczył w międzynarodowym ruchu bibliotekarskim. Sami wnosimy niewiele - kontynuował Kuntze, może poza zagadnieniami statystyki produkcji wydawniczej „która jest niejako domeną polska, dzięki pracy jednostek. Samotne wysiłki Muszkowskiego nie dadzą wiele, trzeba by wybrać kilka naszych domen i w nie zainwestować wspólne wysiłki" ${ }^{11}$.

Te apele nie odniosły skutku - polska elita bibliotekarska była wtedy zbyt szczupła, zbyt przepracowana, by poświęcać swój czas wyłącznie sprawom międzynarodowym. Niewątpliwym plusem była już sytuacja, że jesteśmy obecni w kilku gremiach międzynarodowych i że w ten sposób możemy obserwować trendy rozwojowe i próbować nadążyć za nimi.

${ }^{11}$ Tamże. 


\section{BIBLIOGRAFIA}

Birkenmajer, Aleksander; Grycz, Józef (1938). Les bibliothèques polonaises 1937-38. W: Actes du Comité international des bibliothèques: 11 Session. Bruxelles 4-5 juillet 1938, T. 10. La Haye, s. 162-164.

IV Zjazd Bibliotekarzy Polskich w Warszawie. Dnia 31 maja - 2 czerwca 1936 r. Protokoty, 58 s. (1937). Warszawa.

IV Zjazd Bibliotekarzy Polskich w Warszawie. Dnia 31 maja - 2 czerwca 1936 r. Referaty, cz. I, 351 s., cz. II, 113 s. (1936). Warszawa.

Grycz, Józef (1937). Die polnischen Bibliotheken im Jahre 1936. W: Actes du Comité international des bibliothèques: 10me Session. Paris: Fédération intern. des assoc. de bibliothécaires, s. 163-165.

Kuntze, Edward (1932). Współudział Polski w międzynarodowych pracach bibliotekarskich. Przeglad Biblioteczny, R. 6, s. 115.

Więckowska, Helena (1973). Bibliotekarstwo polskie na terenie międzynarodowym w latach 1923-1939. Studia o Ksiażze, T. 3, s. 197-226.

Artykut wptynat do Redakcji 19 marca 2017 r.

ANDRZEJ MĘŻYŃSKI

e-mail: a.mezynski@gazeta.pl

\section{POLISH LIBRARIANS ASSOCIATION IN IFLA. THE BEGINNINGS OF COOPERATION}

KEYWORDS: Polish Librarians Association 1928-1939. IFLA 1928-1939.

ABSTRACT: Thesis/Objective - the article is intended to recall the background of Polish Librarians Association joining IFLA in 1928 and describe the participation of Polish librarians in IFLA activities including the annual sessions and IFLA subcommittees. Research methods - the author based his research on IFLA Actes du Comité international des bibliothèques and Polish primary and secondary sources related to the subject of the article. Results/Conclusions - Poland joined IFLA very early, gaining the opportunity to follow the latest trends in the international librarianship and implement some of them back home. The contribution of Poland to IFLA activities was not significant at that time - Polish librarianship was still in the process of being formed again after the partitions and no librarianship centers were present. 